\title{
Causes of Elevated Levels of Serum CA 19.9 in Patients without Prior Diagnosis of Malignant Disease
}

\author{
(1) Selcuk Şeber,' (10) Savaş Güzel, ${ }^{3}$ (1) Ahsen Yılmaz, ${ }^{3}$ \\ (1) Sonat Pınar Kara, ${ }^{2}$ (1) Tarkan Yetişyiğit ${ }^{1}$
}

$$
\begin{array}{r}
\text { 'Department of Medical Oncology, } \\
\text { Namık Kemal University Hospital, } \\
\text { Tekirdağ, Turkey } \\
\text { 2Department of Medical } \\
\text { Biochemistry, Namık Kemal } \\
\text { University Hospital, Tekirdağ, Turkey } \\
\text { 'Department of Internal Medicine, } \\
\text { Namık Kemal University Hospital, } \\
\text { Tekirdağ, Turkey }
\end{array}
$$

\begin{abstract}
Objective: Serum CA 19.9 is commonly used as a tumor marker for diagnosis and followup of gastrointestinal malignancies. However, elevated levels can be found in various clinical conditions.
\end{abstract}

Methods: A total of 285 patients whose serum CA 19.9 level was ordered from various outpatient clinics other than oncology in a tertiary hospital setting and who had elevated CA $19.9(>34 \mathrm{U} / \mathrm{mL})$ levels were included in the study group. Statistical analysis of marker levels in relation to diagnosis of patients was performed.

Results: Overall, 226 patients with benign disorders and 59 patients with malignant disease had elevated CA 19-9 levels. One hundred ten (39\%) patients with increased CA 19-9 levels did not have any significant clinical condition associated with high CA 19-9 values. Median CA 19-9 levels were significantly higher in patients with malignancies than in patients with benign disorders $(67.3$ vs. $47.9 ; \mathrm{p}<0.001)$. Receiver operating characteristic curve analysis identified a cut-off value of $66.3 \mathrm{U} / \mathrm{mL}$ for discrimination of malignant from benign gastrointestinal diseases (sensitivity $58.3 \%$ and specificity $82.7 \%$; $\mathrm{p}<0.00 \mathrm{I}$ ).

Conclusion: Serum CA 19-9 levels are significantly higher in patients with malignant diseases. However, there are diverse etiologies associated with elevated serum levels. During chronic inflammatory states, elevated serum CA 19-9 levels can be a frequent finding.

\section{INTRODUCTION}

Although serum CA 19-9 values are commonly used in clinical practice for follow-up and diagnosis of malignant disease, serum levels can increase in a variety of clinical conditions unrelated with cancerous disease and can therefore lead to confusion of the caring medical team and unnecessary diagnostic tests. The aim of the present study was to elucidate the conditions related with increased serum CA 19-9 levels and to analyze whether elevated CA 19-9 levels can distinguish between malignant and benign diseases.

CA 19-9 is a carbohydrate tumor-associated antigen that was first discovered from a colon cancer cell line. ${ }^{[1]}$ It is an O-linked glycoprotein that is expressed as a glycolipid on the cell surface and is also called as sialyl Lewis-a. CA 19-9 production is closely linked to a blood group antigen called as disialyl Lewis-a that has one more sialic acid residue than CA 19-9 and is preferentially synthesized in normal non-malignant gastrointestinal and other organ epithelial cells. However, in cancer cells, because of aberrant sialylation process, sialyl Lewis-a, which is a simpler molecule, is synthesized instead. ${ }^{[2]}$
Increased CA 19-9 production in pancreatic and biliary tumors is a well-known phenomenon. However, increased levels can also be detected in other types of malignant diseases, such as gastric, colorectal, and ovarian cancers. A lesser known fact is that many diverse benign conditions can also lead to increased serum CA 19-9 levels, such as obstructive diseases of the biliary tree. ${ }^{[3]}$

Serum CA 19-9 levels can be used as a marker of tumor response to chemotherapy with a caveat that its presence requires the expression of Lewis blood group antigens, and people with Le $(\alpha-\beta-)$ phenotype cannot express CA 19-9 antigen. Hence, approximately $10 \%$ of the population with this certain phenotype will not be expected to have increased serum CA 19-9 levels even in the presence of advanced gastrointestinal malignancy. ${ }^{[4]}$

\section{MATERIALS AND METHODS}

The study population consisted of all of the patients whom serum CA 19-9 levels were measured from peripheral blood samples between January I, 2016 and December 
30,2017 by the departments other than medical oncology and who had an above reference range value of $34 \mathrm{U} / \mathrm{mL}$ $(n=285)$. Information about the diagnosis of the patients made during the time of the increased serum CA 19-9 level was retrieved from the electronic medical records of the hospital. Serum CA 125 levels were also recorded for patients diagnosed with various gynecological disorders at the time of serum CA 19-9 levels was measured whenever possible. If a specific diagnosis was not recorded at the time of increased serum CA $19-9$ levels, these patients were categorized under the not otherwise specified (NOS) subgroup. Serum CA 19-9 levels were measured by a Roche Cobas E60I immunoassay analyzer (Roche Diagnostics $\mathrm{GmbH}$, Mannheim, Germany) using the electrochemiluminescence immunoassay technique. The normal range was defined as $<34 \mathrm{U} / \mathrm{mL}$ according to the manufacturer's instructions.

The study protocol was approved by the scientific research ethics committee of Namik Kemal University Hospital according to the ethical principles of the Declaration of Helsinki.

\section{Statistical analysis}

Statistical analysis was performed using MedCalc statistical software version 12.7.7 (MedCalc Software Bvba, Ostend, Belgium; http://www.medcalc.org; 2013). Descriptive statistical analysis was used for comparison of continuous variables (mean, median, and standard deviation). Receiver operating characteristic (ROC) curve analysis was used for determining the optimal cut-off value for serum CA 19-9 for differentiating benign and malignant diseases. Fisher's exact test was used for assessment of association between independent categorical variables. Mann-Whitney $U$ test was used for comparison between two groups with non-normal distribution, and Student's t-test was used for comparison of two groups with normal distribution. A pvalue $<0.05$ was considered statistically significant.

\section{RESULTS}

A total of 285 patients with a serum CA $19-9$ level that was higher than the upper limit of reference range $(34 \mathrm{IU} / \mathrm{mL})$ were included in the study group. There were 113 male and 172 female patients $(60.4 \%)$. The median age of the patients was 61 (22-92) years. The median CA 19-9 level of the study group was $44.4(32-99.3) \mathrm{IU} / \mathrm{mL}$ when the outlier values were excluded from the calculation (Table I). The highest CA 19-9 level measured was I,238,500 U/ $\mathrm{mL}$ that belonged to a patient diagnosed with pancreatic cancer. Fifty-nine patients were diagnosed with malignant disease, whereas $79 \%$ of the study population had other benign clinical conditions not related with malignant diseases. Of the 285 patients in the study population, 38\% $(n=110)$ had an elevated CA 19-9 level not associated with any clinical disease and were categorized as NOS. Among malignant diseases, pancreatic cancer was the most common malignancy $(5.3 \%)$, whereas liver cirrhosis was the
Table I. Demographic and laboratory characteristics associated with increased serum CA 19-9 levels $(>37 \mathrm{U} / \mathrm{mL})$

\begin{tabular}{lcc}
\hline & $\mathbf{n}$ & $\%$ \\
\hline Male & $\mathrm{II3}$ & 39.6 \\
Female & $\mathrm{I} 2$ & 60.4 \\
\hline & Median & Mean \\
\hline Age (years) & $59.4 \pm 16.1$ & $61(22-92)$ \\
CA 19.9 $(\mathrm{IU} / \mathrm{mL})$ & $13272.2 \pm 132376$ & $52.8(32-1.74 \mathrm{E}+6)$ \\
CA 19.9 (IU/mL) & $50.1 \pm 15.3$ & $44.4(32-99.3)$ \\
(excluding outliers) & & \\
\hline
\end{tabular}

Table 2. Summary of clinical conditions associated with elevated serum CA 19-9 levels

\begin{tabular}{llcc}
\hline Organ system & Type of diseases & n & $\%$ \\
\hline Gastrointestinal & Cancers of pancreas and & & \\
system & the biliary tract & 24 & 7.4 \\
& Hepatocellular carcinoma & 7 & 2.5 \\
& Gastric carcinoma & 4 & 1.4 \\
& Colorectal cancer & 7 & 2.5 \\
& Hepatitis (viral and & & \\
& other causes) & 9 & 3.1 \\
& Hepatosteatosis & 12 & 4.2 \\
& Pancreatitis, cholecystitis, & & \\
& cholelithiasis & 31 & 10.8 \\
& Cirrhosis due to various & & \\
& etiologies & 17 & 6 \\
Reproductive & Cancers of the ovary & & \\
system & and endometrium & 17 & 6 \\
& Endometriosis, leiomyoma & 19 & 6.6 \\
& Dermoid cyst & 3 & 1 \\
& Ovarian cyst & 13 & 4.5 \\
Hydatid cyst & 2 & 1 \\
Miscellaneous & Sarcoidosis & 2 & 1 \\
diseases & Rheumatoid arthritis & 2 & 1 \\
& Inflammatory bowel & & \\
& disease & 4 & 1.4 \\
& Hemochromatosis & 2 & 1 \\
\hline & & &
\end{tabular}

most common benign condition (4.6\%) associated with increased serum CA 19-9 levels. The clinical conditions that were associated with increased CA 19-9 serum levels are summarized in Table 2. When the median CA 19-9 values of patients with and without malignancy were compared, patients diagnosed with cancer had higher mean CA 19-9 levels than patients without malignant disease $(67.3 \pm 17.8$ vs. $47.9 \pm 13.6 ; p<0.001)$. Even when this comparison is made when patients without clinically significant disease (NOS subgroup) are excluded, the difference continues to be statistically significant $(p=0.0 \mathrm{II})$. When subgroup of patients diagnosed with gynecological and gastrointestinal 
Table 3. Serum CA 19-9 levels $(\mathrm{U} / \mathrm{mL})$ compared in patients diagnosed with and without malignant disorders

\begin{tabular}{|c|c|c|c|c|}
\hline & & Benign & Malignant & $\mathbf{p}$ \\
\hline & & $\begin{array}{c}\text { Mean } \pm \text { SD } \\
\text { Median (Min.-Max.) }\end{array}$ & $\begin{array}{c}\text { Mean } \pm \text { SD } \\
\text { Median (Min.-Max.) }\end{array}$ & \\
\hline \multirow[t]{8}{*}{ CA $19.9 \mathrm{U} / \mathrm{mL}$} & \multirow[t]{2}{*}{ Whole study population } & $47.9 \pm 13.6$ & $67.3 \pm 17.8$ & $<0.001^{* *}$ \\
\hline & & 43.1 (32-99.9) & 67 (37.9-97.2) & \\
\hline & \multirow[t]{2}{*}{ Gastrointestinal system } & $56.9 \pm 12.2$ & $68.7 \pm 20.4$ & \\
\hline & & $57.8(34.1-90.1)$ & 70.9 (37.9-97.2) & $<0.001^{*}$ \\
\hline & \multirow[t]{2}{*}{ Reproductive system } & $54.6 \pm 19.2$ & $65.8 \pm 15.5$ & \\
\hline & & $50.4(34.1-99.9)$ & $59.05(44-86.9)$ & $0.029^{* * *}$ \\
\hline & \multirow[t]{2}{*}{ Whole study population (excluding NOS) } & $56.3 \pm 14.6$ & $67.3 \pm 17.8$ & $0.011^{* *}$ \\
\hline & & $54(34.1-99.9)$ & 67 (37.9-97.2) & \\
\hline
\end{tabular}

NOS: Not otherwise spesified; SD: Standard deviation; Min.: Minimum; Max.: Maximum. *Student's t-test. *Mann-Whitney U test.

Serum CA 19.9 levels were significantly higher in patients diagnosed with malignant disorders than in patients who had benign clinical disorders. The difference remained significant even when patients who had not otherwise specified (NOS) above normal limit CA 19-9 levels were excluded.

Table 4. Cut-off values for CA 19-9 levels for discrimination of benign and malignant disorders

\begin{tabular}{llccccc}
\hline & & AUC & p & Cut-off & Sensitivity & Specificity \\
\hline Ca19.9 (U/mL) & Study population & 0.811 & $<0.001$ & 50.4 & 82.61 & 68.95 \\
& Gastrointestinal system & 0.673 & 0.113 & 66.3 & 58.33 & 82.69 \\
& Reproductive system & 0.731 & 0.006 & 54.0 & 81.82 & 68.00 \\
& Study population (excluding NOS) & 0.674 & 0.009 & 66.3 & 52.17 & 82.72 \\
\hline
\end{tabular}

The area under the curve (AUC) was determined for assessment of diagnostic accuracy. NOS: Not otherwise spesified.

diseases were examined, the serum CA 19-9 levels were significantly higher in patients with malignant diseases than in patients with benign clinical conditions $(p=0.029$ and $\mathrm{P}<0.00 \mathrm{I}$, respectively) (Table 3 ).

A ROC curve analysis was made to determine the cut-off value of serum CA 19-9 levels for discriminating patients with malignant diseases from patients with benign clinical conditions (Fig. I). The cut-off value for differentiating malignant gastrointestinal versus benign gastrointestinal disease was 66.28 with a sensitivity and specificity of 58.3 and 82.7, respectively. The cut-off values for differentiating malignant from benign clinical conditions in other subgroups were also identified (Table 4). There was no correlation found with increasing age and higher serum CA 19-9 levels (Spearman's rho test; $p=0.46$ ). When older individuals are assessed as a separate group, patients with malignant disease had a significantly higher median CA 19-9 serum levels than those without (70 vs. 44.2; $\mathrm{p}<0.00 \mathrm{I}$ ). However, the difference between serum levels did not remain significant when subgroups of patients with gastrointestinal and gynecological disorders were analyzed. The area under the curve for CA 19-9 for both the whole study group and individuals $>60$ years old was $0.8 \mathrm{II}$ that marked the optimal cut-off values for serum CA 19-9 levels for differentiating malignant disease from benign clinical conditions as 50.4 and 62.4 , respectively.

Mean serum CA 19-9 levels in the NOS group were significantly lower than those in patients diagnosed with a specific benign clinical condition (4I.8 \pm 8.7 vs. $56.3 \pm 14.6$;
$\mathrm{P}<0.00 \mathrm{I}$, respectively). When the study group was analyzed in patients $>60$ years, serum CA 19-9 levels remained significantly higher in patients with malignant diseases than in patients with benign clinical conditions $(69.3 \pm 19.2$ vs. 48.I $\pm 12.9 ; p<0.001$, respectively).

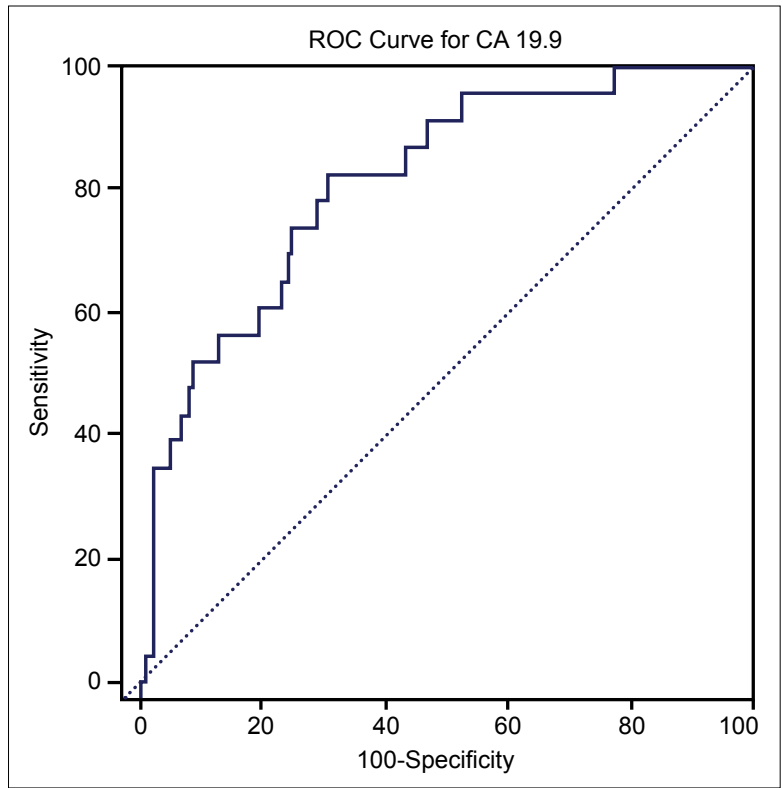

Figure 1. ROC curve analysis for serum CA 19-9 for differentiating benign clinical conditions from malignant diseases. The area under the curve is 0.811 . 


\section{DISCUSSION}

We documented that serum CA 19-9 levels are significantly higher in patients with malignant disease than in those with benign clinical conditions, and a cut-off value can be determined for differentiating benign conditions from malignant ones. However, serum CA 19-9 levels can be found elevated in many diverse clinical conditions. Although upper pancreas, biliary tree, and liver diseases appear to be the most common etiologies, conditions, such as rheumatologic diseases, inflammatory disorders, and benign gynecological conditions, such as dermoid cysts, can also give rise to increased serum levels. ${ }^{[5]}$ Therefore, a higher value for serum CA 19-9 could be more appropriate for suspecting a malignant disease rather than the reference value provided by the central laboratory to avoid unnecessary diagnostic procedures.

The clinician must keep in mind that approximately 10\% of the population do not express CA 19-9 because of the Lewis $(\alpha-\beta-)$ phenotype, and in addition, approximately $5 \%$ of the tumors may gain epigenetic mutations and cease to express CA 19-9 on the course of the disease. ${ }^{[6]}$ Therefore, below reference range CA 19-9 serum levels do not rule out the presence of malignant disease even for cases of gastrointestinal malignant disease in which CA 19-9 is commonly used as a tumor marker.

Whether serum CA 19-9 levels can be utilized for distinguishing malignant from benign disease is a debated subject in the literature. There are several studies in the literature that show that CA 19-9 cannot differentiate between malignant and benign clinical conditions. ${ }^{[7,8]}$

However, there are other studies that report cut-off values for CA 19-9 levels for distinguishing between malignant and benign diseases as well. We believe that setting a higher threshold for serum CA 19-9 levels can be more sensitive in selecting patients who might have a malignant condition, especially with regard to diseases associated with the gastrointestinal system. ${ }^{[9]}$

The cut-off value for distinguishing malignant from benign gastrointestinal disorders was 66.3 in our study. In a similar study by Morris-Stiff et al., the cut-off value reported for differentiating malignant from benign conditions related to the gastrointestinal system was $70.5 \mathrm{U} / \mathrm{mL}$, which is almost similar to our findings. ${ }^{[10]}$

Another important issue that should be taken into account is the existence of jaundice. In the presence of obstructive jaundice, the expression of CA 19-9 increases dramatically regardless if the cause is malignant or not. Therefore, some authors suggest that serum CA 19-9 is a better indicator for distinguishing malignant from benign gastrointestinal disease when jaundice is not present. ${ }^{[7]}$

An important caveat when interpreting high serum CA 19-9 levels is that it is not a specific marker for gastrointestinal disorders. Serum CA 19-9 levels have been reported to be elevated in benign gynecological conditions, such as dermoid cysts, mucinous cystadenomas, and be- nign ovarian cysts, as well as malignancies, such as epithelial ovarian carcinomas and borderline ovarian tumors. ${ }^{[1,12]}$ Endometrial cancer and endometriomas may also cause elevated levels of serum CA 19-9. Serum CA 125 is another tumor marker that is widely used for diagnosis and follow-up of various types of gynecological tumors. In fact some studies have even suggested that the combined use of serum CA $19-9$ and CA 125 may be a better method for detecting early recurrence in endometrial cancers. ${ }^{[13]}$

In our study, we also evaluated whether the combination of increased CA 125 levels along with increased CA 19-9 levels could discriminate benign and malignant gynecological tumors. CA I 25 levels were also found to be simultaneously elevated in $68 \%$ of the gynecological cancer cases, whereas its levels were elevated in $45 \%$ of the benign gynecological disorders in combination with elevated serum CA 19-9 levels. The combined elevation of the two serum markers was not found to be significantly related with the presence of malignancy $(p=0.55)$. Although several case reports and retrospective studies have documented elevated CA 125 and CA 19-9 serum levels in the presence of both benign and malign diseases related to the gynecological system, the assessment of whether the combination of high CA 125 and CA 19-9 levels can discriminate between benign and malignant conditions was not previously reported..$^{[14,15]}$

As previously mentioned, in their very large prospective study, Kim et al. assessed the positive predictive value of serum CA 19-9 for detecting pancreatic cancer in the healthy population. The mean value of CA 19-9 in subjects whose CA 19-9 level was above threshold $(>37 \mathrm{U} / \mathrm{mL})$ was 50.5 , which is almost similar to our finding of 50.I. They reported that $20 \%$ of the subjects with above reference range CA 19-9 levels have a malignant disease, and in $67 \%$ of the subjects, no clinical condition that could explain the elevated CA 19-9 levels was detected8. In our study group, we report a similar percentage of subjects diagnosed with cancer (20.7\%); however, the frequency of people with no apparent clinical condition (categorized as NOS), which can be directly linked with high CA 19-9 levels, remained at $38.6 \%$. One plausible explanation for this observation could be that in this very large screening study, the main aim was to detect pancreatic cancer. Therefore, other possible causes, such as chronic inflammatory conditions and miscellaneous diseases, such as sarcoidosis, could have been overlooked, whereas in our study, meticulous search of medical records enabled us to detect diverse etiologies that have been linked with increased serum CA 19-9 levels in the literature.

We have documented several cases of benign inflammatory conditions associated with increased CA 19-9 levels, such as rheumatoid arthritis, inflammatory bowel disease, and sarcoidosis, in our study cohort. Although elevated serum CA I5.3 levels have been reported in patients with sarcoidosis before, to our knowledge, this is the first study reporting increased serum CA 19-9 levels in two patients with sarcoidosis. ${ }^{[16]}$ Elevated levels of CA 19-9 have been linked with conditions associated with increased pulmonary fibrosis. Our finding of increased CA 19-9 levels 
in patients with sarcoidosis can be also associated with the regeneration of epithelial cells associated with chronic inflammation in the lung parenchyma. ${ }^{[17]}$ The reason behind the elevation of serum CA 19-9 in the presence of inflammation is uncertain. Even in diseases primarily involving the biliary tract, it has been proposed that the degree of inflammation is more strongly associated with CA 19-9 levels rather than the degree of biliary obstruction. ${ }^{[18]}$

Fucosylation, which is the addition of fructose molecules to glycoproteins, is heavily upregulated in the presence of inflammatory conditions and in cancer and plays an important role in the cellular proliferation and regulation of growth factor receptors. Therefore, increased levels of fucosylated oligosaccharides, such as CA 19-9, can be detected in clinical conditions where inflammation plays a major role. ${ }^{[19]}$

In conclusion, we showed that median serum CA 19-9 levels are higher in gastrointestinal malignant tumors than in benign disorders involving the liver, pancreas, and biliary system. Using a cut-off value by ROC curve analysis, the sensitivity of serum CA 19-9 can be increased for differentiation of malignant and benign clinical conditions, especially in the case of diseases related to the pancreaticobiliary system.

Physicians must keep in mind that there are many conditions linked to increased serum CA 19-9 levels other than cancer, as increased CA 19-9 levels may be indicative of the presence of chronic inflammatory disease. Our results suggest that serum values very close to the upper reference limit are most likely be of less clinical importance and are not likely to be associated with any clinical disease. Careful assessment of patient's medical history, symptoms, and appropriate imaging procedures will be sufficient in most cases when evaluating the etiology of increased serum CA 19-9 levels.

Ethics Committee Approval

All procedures performed in studies involving human participants were in accordance with the ethical standards of the institutional research committee and with the Declaration of Helsinki and its later amendments or comparable ethical standards. The study was approved by Namık Kemal University Hospital Ethical Committee (decision no.: $2017 / 125 / 12 / 13)$.

Informed Consent

Retrospective study.

Peer-review

Internally peer-reviewed.

Authorship Contributions

Concept: S.Ş., S.G., A.Y., T.Y., S.P.K.; Design: S.Ş., S.G., A.Y., T.Y., S.P.K.; Data collection \&/or processing: A.Y., S.P.K.; Analysis and/or interpretation: A.Y., S.G.; Literature search: T.Y., S.P.K.; Writing: S.Ş., T.Y.; Critical review: S.Ş., S.G., A.Y., T.Y., S.P.K.

Conflict of Interest

None declared.

\section{REFERENCES}

1. Del Villano BC, Brennan S, Brock P, Bucher C, Liu V, McClure M, et al. Radioimmunometric assay for a monoclonal antibody-defined tumor marker, CA 19-9. Clin Chem 1983;29:549-52.

2. Tuccillo FM, de Laurentiis A, Palmieri C, Fiume G, Bonelli P, Borrelli A,et al. Aberrant glycosylation as biomarker for cancer: focus on CD43. Biomed Res Int 2014;2014:742831. [CrossRef]

3. McLaughlin R, O'Hanlon D, Kerin M, Kenny P, Grimes H, Given HF. Are elevated levels of the tumour marker CA19-9 of any clinical significance?--an evaluation. Ir J Med Sci 1999;168:124-6. [CrossRef]

4. Luo G, Liu C, Guo M, Cheng H, Lu Y, Jin K, et al.Potential Biomarkers in Lewis Negative Patients With Pancreatic Cancer. Ann Surg 2017;265:800-805. [CrossRef]

5. Scarà S, Bottoni P, Scatena R. CA 19 9: Biochemical and Clinical Aspects. Adv Exp Med Biol 2015;867:247-60. [CrossRef]

6. Barnett D, Liu Y, Partyka K, Huang Y, Tang H, Hostetter G, et al. The CA19-9 and Sialyl-TRA Antigens Define Separate Subpopulations of Pancreatic Cancer Cells. Sci Rep 2017;7:4020. [CrossRef]

7. Lin MS, Huang JX, Yu H. Elevated serum level of carbohydrate antigen 19-9 in benign biliary stricture diseases can reduce its value as a tumor marker. Int J Clin Exp Med 2014;7:744-50.

8. Kim JE, Lee KT, Lee JK, Paik SW, Rhee JC, Choi KW. Clinical usefulness of carbohydrate antigen 19-9 as a screening test for pancreatic cancer in an asymptomatic population. J Gastroenterol Hepatol 2004;19:182-6. [CrossRef]

9. Pavai S, Yap SF. The clinical significance of elevated levels of serum CA 19-9. Med J Malaysia 2003;58:667-72.

10. Morris-Stiff G, Teli M, Jardine N, Puntis MC. CA19-9 antigen levels can distinguish between benign and malignant pancreaticobiliary disease. Hepatobiliary Pancreat Dis Int 2009;8:620-6.

11. Chen F, Shen J, Wang J, Cai P, Huang Y. Clinical analysis of four serum tumor markers in 458 patients with ovarian tumors: diagnostic value of the combined use of HE4, CA125, CA19-9, and CEA in ovarian tumors. Cancer Manag Res 2018;10:1313-1318. [CrossRef]

12. Coskun A, Kiran G, Ozdemir O. CA 19-9 can be a useful tumor marker in ovarian dermoid cysts. Clin Exp Obstet Gynecol 2008;35:137-9.

13. Takeshima N, Shimizu Y, Umezawa S, Hirai Y, Chen JT, Fujimoto I, et al. Combined assay of serum levels of CA125 and CA19-9 in endometrial carcinoma. Gynecol Oncol 1994;54:321-6. [CrossRef]

14. Kyung MS, Choi JS, Hong SH, Kim HS. Elevated CA 19-9 levels in mature cystic teratoma of the ovary. Int J Biol Markers 2009;24:52-6. [CrossRef]

15. Matalliotakis IM, Goumenou AG, Mulayim N, Karkavitsas N, Koumantakis EE. High concentrations of the CA-125, CA 19-9 and CA 15-3 in the peritoneal fluid between patients with and without endometriosis. Arch Gynecol Obstet 2005;271:40-5. [CrossRef]

16. Colomer R, Ruibal A, Genollá J, Rubio D, Del Campo JM, Bodi R, et al. Circulating CA 15-3 levels in the postsurgical follow-up of breast cancer patients and in non-malignant diseases. Breast Cancer Res Treat 1989;13(2):123-33. [CrossRef]

17. Kodama T, Satoh H, Ishikawa H, Ohtsuka M. Serum levels of CA19-9 in patients with nonmalignant respiratory diseases. J Clin Lab Anal 2007;21:103-6. [CrossRef]

18. Wannhoff A, Rupp C, Friedrich K, Brune M, Knierim J, Flechtenmacher C, et al. Inflammation But Not Biliary Obstruction Is Associated With Carbohydrate Antigen 19-9 Levels in Patients With Primary Sclerosing Cholangitis. Clin Gastroenterol Hepatol 2015;13:2372-9. [CrossRef]

19. Miyoshi E, Moriwaki K, Nakagawa T. Biological function of fucosylation in cancer biology. J Biochem 2008;143:725-9. [CrossRef] 


\section{Daha Önce Malignite Tanısı Konmamış Hastalarda Yüksek Serum CA 19.9 Düzeylerinin Nedenleri}

Amaç: Serum CA 19.9 değerleri gastrointestinal sistem kaynaklı malignitelerin tanısı ve takibinde sık kullanılan bir tümör belirtecidir ancak pek çok farklı klinik durumda serum CA 19.9 değerlerinden yükseklikler ortaya çıkabilir.

Gereç ve Yöntem: Onkoloji kliniği haricindeki polikliniklerden serum CA 19.9 düzeyi incelenmiş ve üst referans limitin üzerinde CA 19.9 değeri saptanmış olan toplam 285 hasta çalışma grubuna dahil edildi. CA 19.9 düzeyleri ile hastaların tanıları arasındaki olası ilişkiler istatistiksel analiz yöntemleriyle geriye dönük olarak incelendi.

Bulgular: Hastaların 226'sında benign hastalıklar artmış CA 19.9 düzeyleri ile ilişki bulunmuş iken 59 hastada malignite saptandı. Yüz on (\%39) hastada ise artmış CA 19.9 değerleri herhangi bir klinik durum ile ilişkilendirilmedi. Medyan serum CA 19.9 değerleri malign hastalığı olanlarda, diğer bireylere göre anlamlı olarak yüksek saptandı $(67.3$ ve $47.9 ; p<0.00$ I). Receiver operating characteristic (ROC) analizi ile malign ve benign hastalıkların ayrımı için kestirim değer $66.3 \mathrm{U} / \mathrm{mL}$ bulundu (duyarılık \%58.3, özgüllük $82.7 \% ; p<0.00 \mathrm{I}$ ).

Sonuç: Serum CA 19.9 değerleri malign hastalığı olan bireylerde benign hastalı̆ıı olanlara göre anlamlı olarak yüksektir ancak serum düzeylerinde aşırı yükselmelerin pek çok farklı sebebi olabilir. Özellikle kronik enflamatuvar süreçlerde yüksek serum CA 19.9 düzeylerinin sık karşılaşılan bir bulgu olduğu akılda tutulmalıdır.

Anahtar Sözcükler: CA 19.9; enflamasyon; malignite. 